\title{
Physical therapy of middle-aged women after the hip joint replacement
}

\author{
Bezyazychna O.V., Manucharian S.V., Duhina L.V. \\ Kharkiv State Academy of Physical Education
}

DOI: https://doi.org/10.34142/HSR.2019.05.02.01

\begin{abstract}
Bezyazychna O.V., Manucharian S.V., Duhina L.V. Physical therapy of middle-aged women after the hip joint replacement

The purpose of the work: development and experimental substantiation of a physical therapy program for middle-aged women after the hip joint replacement.

Material and methods. 22 middle-aged women after hip joint replacement (the non-cement form of fixation of the prosthesis components) during the training period took part in the experiment; they were divided into two groups, experimental and control one, 11 people in each. Women in the experimental group underwent physical therapy measures according to the author's program, and women of the control group underwent it according to the physical therapy program for individuals after the hip joint replacement.

Pedagogical and medico-biological studies were conducted for 3 months. Primary and repeated study involved clinical methods (history collection, physical examination); assessment of the quality of life, as well as medical and pedagogical observations in the process of remedial gymnastics and mathematical statistics methods.

Results. We present the program of physical therapy using remedial gymnastics based on step-down exercises with visual control and exercises with an elastic band on a healthy leg for balance training; therapeutic massage; physiotherapy according to conventional methods, namely: electromyostimulation; laser therapy.

Conclusion. In the course of the study conducted, we came to the conclusion that the program of physical therapy for middle-aged women after hip joint replacement in the training period, developed and implemented in the Utility Non-Profit Enterprise of Kharkiv Oblast Council "Oblast Clinical Hospital" has allowed to increase the efficacy of rehabilitation; it is available to all specialized rehabilitation centers, and deserves a wide-scale implementation into practice.
\end{abstract}

Key words: physical therapy, endoprosthesis replacement, quality of life.

\section{Анотація}

Без'язична О.В., Манучарян С.В., Дугіна Л.В. Фізична терапія жінок середнього віку після ендопротезування кульшового суглоба. Мета роботи: розробити і експериментально обгрунтувати методику фізичної терапії для жінок середнього віку після ендопротезування кульшового суглоба.

Матеріал і методи. В експерименті брали участь 22 жінки середнього віку після ендопротезування кульшового суглоба (безцементний спосіб фіксації компонентів ендопротеза) у тренувальному періоді, які були розподілені на дві групи експериментальну і контрольну, в кожній по 11 осіб. Жінкам експериментальної групи заходи фізичної терапії проводилися за авторською програмою, жінкам контрольної групи - за програмою фізичної терапії для осіб після ендопротезування кульшового суглоба. Педагогічні та медико-біологічні дослідження проводились протягом трьох місяців. При первинному і повторному дослідженні застосовувалися клінічні методи (збір анамнезу, зовнішній огляд), оцінка якості, а також лікарсько-педагогічні спостереження в процесі занять лікувальною гімнастикою і методи математичної статистики.

Результати. Представлена програма фізичної терапії із застосуванням лікувальної фізичної культури на основі степ-даун вправ 3 візуальним контролем та вправ з еластичною стрічкою на здоровій нозі для тренування балансу; лікувального масажу; фізіотерапії за стандартними методиками, а саме: електроміостимуляції; лазерної терапії.

Висновки. В ході проведеного дослідження ми прийшли до висновку, що розроблена і впроваджена в Комунальне некомерційне підприємство Харківської Обласної Ради «Обласна клінічна лікарня» програма фізичної терапії для жінок середнього віку після ендопротезування кульшового суглоба у тренувальному періоді дозволила підвищити ефективність відновного лікування, доступна для всіх спеціалізованих реабілітаційних центрів та заслуговує широкого впровадження в практику.

Ключові слова: фізична терапія, ендопротезування, якість життя.

\section{Аннотация}

Безъязычная О.В., Манучарян С.В., Дугина Л.В. Физическая терапия женщин среднего возраста после эндопротезирования тазобедренного сустава.

Цель работы: разработать и экспериментально обосновать програму физической терапии для женщин среднего возраста после эндопротезирования тазобедренного сустава.

Материал и методы. В эксперименте принимали участие 22 женщины среднего возраста после эндопротезирования тазобедренного сустава (бесцементный способ фиксации компонентов эндопротеза) в тренировочном периоде, которые были разделены на две группы - экспериментальную и контрольную, в каждой по 11 человек. Женщинам экспериментальной группь физическая терапия проводилась по авторской программе, женщинам контрольной группы - по программе физической терапии для лиц после эндопротезирования тазобедренного сустава. Педагогические и медико-биологические исследования проводились в течение 3 месяцев. При первичном и повторном исследовании применялись клинические методы (сбор анамнеза, внешний осмотр), оценка качества жизни, а также врачебно-педагогические наблюдения в процессе занятий лечебной гимнастикой и методы математической статистики.

Результаты. Представленная программа физической терапии с применением лечебной физической культуры на основе степдаун упражнений с визуальным контролем и упражнений с эластичной лентой на здоровой ноге для тренировки баланса; лечебного массажа; физиотерапии по стандартным методикам, а именно: электромиостимуляции; лазерной терапии.

Выводы. В ходе проведенного исследования мы пришли к выводу, что разработанная и внедренная в Коммунальное некоммерческое предприятие Харьковского областного Совета «Областная клиническая больница» программа физической терапии для женщин среднего возраста после эндопротезирования тазобедренного сустава в тренировочном периоде позволила повысить эффективность восстановительного лечения, доступна для всех специализированных реабилитационных центров и заслуживает широкого внедрение в практику.

Ключевые слов а: физическая терапия, эндопротезирование, качество жизни. 


\section{Introduction}

The hip joint holds a special place in the biomechanical connection of the lower extremity and the spine. It has three degrees of freedom and three axes of motion. With wide functionality, this joint assumes considerable dynamic and static loads, providing harmony of movement of the person. With the development of pathology in the joint, severe functional disorders occur throughout the lower extremity, which subsequently leads to disorders throughout the musculoskeletal system. Disability and pain make patients with disabilities. In recent years, one of the most effective and promising methods of surgical treatment is joint replacement [1, $2,3]$.

According to the WHO expert group in 2012, 1 million 500 thousand total hip replacement is performed worldwide. The number of operations in the last 5 years has increased in Europe by $80 \%$, which is 175 thousand a year in one Germany alone. That is, world statistics show that on average annually requires joint replacement of $500-1000$ patients and injured per 1 million population, and given the population of Ukraine, annually in our country requires endoprosthesis 25-40 thousand patients and injured. Unfortunately, 10 times less than the estimated number of joint replacements is performed annually in Ukraine. As is known, osteoarthritis of the hip joint is almost inevitable consequence of any diseases and injuries of the hip joint. Therefore, any method of treatment other than total endoprosthetics cannot prevent its development, at best it can only slow the progression of osteoarthritis $[4,5]$.

An important and not completely resolved issue in endoprosthetics is the problem of recovery of patients after joint replacement. At present, there are few such centers in the country, and there are no accurate data on the total number of such patients, the results of their treatment, etc. At the same time, these patients require routine physical therapy, which should be performed in specially organized or specially equipped rehabilitation centers. Successful and biomechanically correct recovery of patients requires adequate pre- and postoperative physical therapy programs $[6,7,8]$.

The purpose of the work: evaluate the impact of the author's physical therapy program on the quality of life of middle-aged women after hip replacement in the training period.

Tasks of work:

1. Based on the study of specialized literature to analyze the main approaches to physical therapy after hip replacement.
2. Improve and implement a program of physical therapy for middle-aged women after hip replacement in the training period.

3. To evaluate the effectiveness of the implemented physical therapy program on the basis of the quality of life assessment according to the Johanson questionnaire and Harris scale [7].

\section{Material and methods}

\section{Participants}

The study is based on the results of a survey of 22 women after hip replacement, who were arbitrarily divided into two groups - experimental $(n=11)$ and control $(n=11)$. The mean age in the experimental group was $49.09 \pm 0.81$ and in the control group was $51.00 \pm 0.72$. All patients with hip joint prosthetics were performed in the orthopedictraumatology department of the Municipal non-profit enterprise of Kharkiv Regional Council "Regional Clinical Hospital", a cementless method of fixation of components of the endoprosthesis. In terms of the number of patients, age, presence of concomitant pathology, the groups were homogeneous (Tab. 1).

\section{Experimental protocol}

According to the analysis of medical histories in the hospital, physical therapy activities began from the first day after surgery: therapeutic exercises (breathing exercises, isometric exercises for the operated limb in the initial position lying on the back), for 2-3 days after endoprosthesis, the patient was verticalized and assigned to stroke. with additional support (walkers 1-2 days, then crutches). From the second week was prescribed electromyostimulation and mechanotherapy. Patients were in the hospital 7-10 days after surgical treatment (before removal of sutures).

The initial study was performed within 1-2 days of the training period, and the second study 3 months after the application of physical therapy measures at the Municipal Non-Profit Enterprise of Kharkiv Regional Council "Regional Clinical Hospital".

Part of them (11 patients) subsequently underwent physical therapy according to our author's program, and part (11 patients) were engaged in the program Epifanov [9] (department of the clinic in which they were treated).

Thus, the first (11 patients) was an experimental group and the second (11 patients) was the control group.

In the initial study, the quality of life indicators of patients on the Harris scale [7] in the 
experimental and control groups were rated as "unsatisfactory". According to the Johanson questionnaire, the mean score in the experimental group was $44.45 \pm 0.57$, and in the control group $48.72 \pm 0.63$, which is below the mean.
When comparing indicators in patients of both groups, we found no statistically significant differences $(p>0.05)$ (Table 1).

Indicators of quality of life of patients after endoprosthesis

hip joint in the initial study $\left(\bar{x}_{ \pm \mathrm{m}}\right)$

\begin{tabular}{lcccc}
\hline \multicolumn{1}{c}{ Questionnaire, scores } & $\begin{array}{c}\text { Experimental } \\
\text { group, } \mathrm{n}=11\end{array}$ & $\begin{array}{c}\text { Control group, } \\
\mathrm{n}=11\end{array}$ & $\mathrm{t}$ & $\mathrm{p}$ \\
\hline Harris Scale [7] & $47,45 \pm 0,57$ & $48,72 \pm 0,63$ & 1,48 & $>0,05$ \\
\hline Johanson System [7] & $44,45 \pm 0,36$ & $46,00 \pm 0,60$ & 2,09 & $>0,05$ \\
\hline
\end{tabular}

The methodological bases of the developed physical therapy program included:

- selection and determination of rational orientation of physical rehabilitation means;

- justification of various means of physical rehabilitation and their dosage;

- defining the criteria for their effectiveness.

The program envisaged the use of the following measures:

- therapeutic physical education;

- therapeutic massage;

- physiotherapy by standard methods, namely: electromyostimulation; laser therapy.

Tasks of therapeutic physical culture:

- promotion of the condition of the musculoskeletal system;

- restoration of walking skills without additional support;

- adaptation to certain power and speed voltages, to long static and dynamic loads in daily life;

- restoration of statin dynamic balance, coordination of movements.

Forms of therapeutic physical culture:

- therapeutic gymnastics;
- therapeutic walking;

- independent classes.

Therapeutic gymnastics by individual or small group method (40-60 minutes, daily, № 30-40).

The basis of the medical gymnastics complexes were step-down exercises with visual control and exercises with an elastic band on a healthy leg for balance training.

Step-down exercises begin with a low step (10 $\mathrm{cm}$ high). The patient stands on the steppe and takes a slow step with a healthy leg forward, descending from the steppe. The body weight is kept on the sore leg, which will also train the balance.

There should be a mirror in front of the patient so that the patient can look at themselves from the side while controlling the position of the feet and thighs - it is very important to make sure that when stepping down from the steppe there is no blockage to the side of the patient's leg. They then return to the starting position and repeat the exercise.

The number of repetitions 12-18 times.

If the exercise is performed correctly, the height of the steppe is gradually increased (15 and 20 centimeters) (Fig. 1).

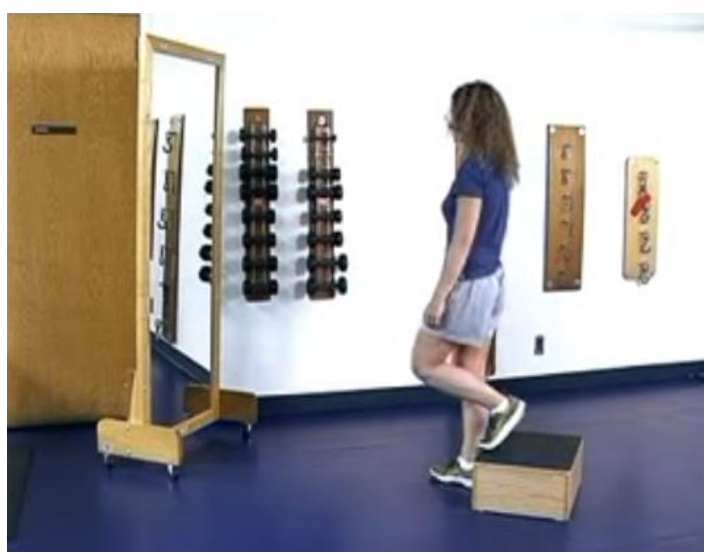

Fig. 1. Step-down exercise with visual control

Exercise with an elastic band on a healthy leg for balance training: the loose ends of an elastic band about 2 meters long are tied to a stationary object about 20 centimeters above the floor (for 
example, the crossbar of a Swedish wall). Thus, a loop about 1 meter in length is obtained. Standing on a diseased leg, the patient puts this loop on a healthy leg so that the loop is at the level of the bone. The patient should stand about 60-70 centimeters from the wall. The knees should be slightly bent, but the torso should be kept straight. A healthy leg (on which a loop of elastic band is worn) starts to move sideways. This exercise trains the muscles of both legs, but first of all, the coordinated work of the muscles - the so-called balance training (Fig. 2). The number of repetitions 12-18 times.

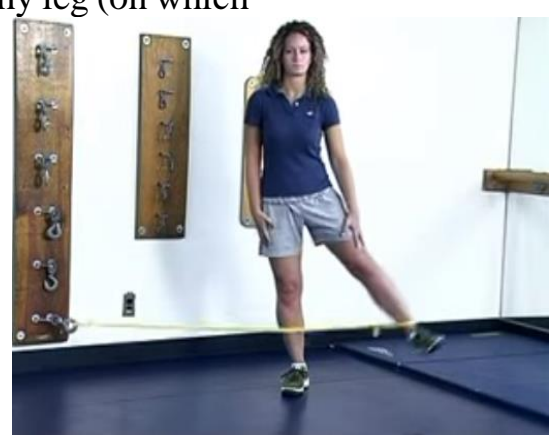

Fig. 2. Exercise with an elastic band on a healthy one legs for balance training

Massage of the lumbosacral spine and lower extremity according to the method of Efimenko [10], daily, № 10-12.

In the training period after hip arthroplasty, it is recommended to massage the paravertebral zones - spinal segments S5 - S1, L5 - L1, as well as massage the operated limb.

Buttocks massage, techniques: stroking, squeezing, kneading, rubbing, shock techniques, shaking.

Thigh massage, techniques: stroking, surface grinding, kneading, deep rubbing, shock techniques, shaking.

Finish the massage with general broad stroke strokes of the diseased limb, passive and active movements. For contractures and stiffness in the joint, apply redressing movements.

To restore joint mobility, Efimenko [10] first recommends massaging his muscular antagonists, which move him, and carefully rub his muscle sinews and directly injured joint. First wide and superficial, then local and deep receptions. After such preparation, passive translational and elastic movements restore its flexibility in the necessary directions. periodically elastic movements alternate with motions at full amplitude. In order to eliminate the pain that occurs during these techniques, the joint is repeated surface rubbing and stroking.

Electromyostimulation of the operated limb muscles in order to increase their strength was performed using the 8-channel Mioritm 040 electromyostimulation apparatus (Russia), changing the frequency and procedure time individually according to the stimulation response of the muscles. Electromyostimulation was performed in the annular mode of the thigh muscles (anterior and posterior group) and the shin muscles of the operated limb in the following sequence: anterior thigh muscle group (4 seconds), posterior (4 seconds), tibia muscles: group flexors (4 seconds) and extensors (4 seconds). Pulse shape asymmetric bipolar without constant component, pulse duration $0.3 \mathrm{~ms}$. Stimulation mode - $60 \mathrm{~Hz}$, duration of the cycle "stimulation relaxation" 4 seconds with an increase to 8 seconds with 5-6 procedures with positive dynamics and good transfer of procedures, duration of the procedure 510-30 minutes, daily, No. 12.

Laser therapy was performed once a day with the help of the laser therapy company "EME" (Italy) according to the standard method, the duration of the procedure - 1 minute for each point, 4 points for the procedure. The procedures were performed according to the zonal - point method: 1 minute per contact zone. On a course of 10 procedures daily [11].

Patients of the control group were prescribed physical therapy measures by Epifanov [9].

The program envisaged the use of the following measures:

- therapeutic physical education;

- therapeutic massage;

- physiotherapy by standard methods, namely: electromyostimulation; laser therapy.

Special tasks of therapeutic physical culture:

- recovery of hip function;

- normalization of trophic tissue of the joint;

- strengthening of muscles of a pelvic belt and extensors of a back, and also strengthening of muscular groups of a limb;

- restoration of their endurance to considerable static and dynamic loads in order to unload and stabilize the operated joint.

Forms of therapeutic physical culture:

- therapeutic gymnastics; 
- therapeutic walking;

- independent classes.

In the gymnastics of physical exercises against the background of developmental and respiratory exercises used to restore and strengthen the muscles, eliminate stiffness and contractures in the injured lower extremity prescribe exercises with objects and without, on stretching, with resistance or counteracting, with exercise water, the simplest elements of occupational therapy, varieties of walking, exercise on simulators.

In the course of rehabilitation treatment varieties of therapeutic walking were used: walking sideways, walking types at a predetermined pace and with a predetermined length of stride.

The course of massage was divided into preparatory, main and final periods.

In the main period, a clearly differentiated method of massage was applied, taking into account the functional state of the patient. The intensity of the techniques was constantly increased, using 8-16 procedures.

Massage of the hip joint and hip muscles was performed according to the method of Epiphanes [9].

In each of the periods of rehabilitation, the methods of hardware physiotherapy were applied according to standard methods: electromyostimulation, laser therapy [11].

\section{Results}

When re-examining quality of life indicators, positive changes were identified. Significant differences were noted when comparing the results of the questionnaires in the dynamics. It was found that in the course of physical therapy there was a significant increase in quality of life indicators.

In the experimental group, the mean Harris score [7] increased by 31.54 points ( 1.7 times), in the control group - by 28.18 (1.5 times) (p <0.05). However, it should be noted that in the experimental group in 55\% the results were rated as "satisfactory", in $45 \%$ as "good" and in the control group - $82 \%$ and $18 \%$ respectively.

According to the Johanson questionnaire [7], in the experimental group the average score increased by 28.00 points (1.6 times), in the control group - by 20.27 (1.4 times) ( $\mathrm{p}<0.05)$. The figures in both groups are above average.

When comparing repeated measures in both groups, we found a statistically significant improvement in indicators in the experimental group compared with the control group $(\mathrm{p}<0.05)$ (Table 2$)$.

Dynamics of quality of life indicators of patients of the main and control groups in the primary and reexamination $(\bar{x} \pm \mathrm{m})$

\begin{tabular}{ccccc}
\hline Questionnaire, scores & I research & II research & $\mathrm{t}$ & $\mathrm{p}$ \\
\hline \multicolumn{5}{c}{ Experimental group $(\mathrm{n}=11)$} \\
\hline Harris Scale [7] & 2 & $79,09 \pm 0,62$ & 4 & 5 \\
\hline Johanson System [7] & $47,55 \pm 0,57$ & $72,45 \pm 0,59$ & 44,49 & $<0,05$ \\
\hline & $44,45 \pm 0,36$ & 48,94 & $<0,05$ \\
\hline Harris Scale [7] & $48,72 \pm 0,63$ & Control group $(\mathrm{n}=11)$ & $<0,05$ \\
\hline Johanson System [7] & $46,00 \pm 0,60$ & $76,09 \pm 0,83$ & 24,20 & $<0,05$ \\
\hline
\end{tabular}

Comparing the quality of life of women in both groups, we came to the conclusion that when they were re-examined in the experimental group after the application of physical therapy measures

under our advanced program, they were better, which positively affects the quality of life of this contingent of persons $(\mathrm{p}<0,05)$ (Table 3$)$.

Comparative characteristics of quality of life of patients after hip replacement at repeated examination

$$
(\bar{x} \pm \mathrm{m})
$$

\begin{tabular}{lcccc}
\hline \multicolumn{1}{c}{ Questionnaire, scores } & $\begin{array}{c}\text { Experimental } \\
\text { group, } \mathrm{n}=11\end{array}$ & $\begin{array}{c}\text { Control group, } \\
\mathrm{n}=11\end{array}$ & $\mathrm{t}$ & $\mathrm{p}$ \\
\hline Harris Scale [7] & $79,09 \pm 0,62$ & $76,09 \pm 0,83$ & 2,87 & $<0,05$ \\
\hline Johanson System [7] & $72,45 \pm 0,59$ & $66,27 \pm 0,87$ & 5,84 & $<0,05$ \\
\hline
\end{tabular}




\section{Discussion}

Analyzing the programs of physical therapy after hip replacement, we can say that they are all based on the same statement, for the maximum restoration of motor functions and return to previous conditions of life, requires the early start of physical therapy. Physical therapy of individuals after hip replacement is important because it can reduce the recovery period of muscle strength that performs movements in the hip joint.

Therapeutic gymnastics is prescribed by the methods of Glinyana [12], Populakh [13], Glynyana [14], Mukhin [16], Babov [1, 4], Zamorsky [5], Gerasimenko [13], Roy [17, 18].

Gliniana $[12,14]$ offers several periods of physical rehabilitation: preoperative (14 days), early postoperative (1-7 days after surgery), late postoperative (5-7 to 17-21 days after surgery), recovery (from 17- 21 days to 10-12 weeks after surgery) and training (10-12 weeks to 24 weeks after surgery) periods.

Gliniana [12] proposes a physical therapy program for the elderly after cement arthroplasty and outlines the following principles:

1. A rational combination of methods and means of physical therapy at all periods, taking into account the features of surgery.

2. Differential use of physical therapy depending on concomitant diseases.

3. Consistent correction of functional disorders in accordance with the tasks of each period of physical rehabilitation. Also, for each of the periods listed there are defined their terms and physical activities that are characteristic of these periods.

Pollyakh [13] offers his work with patients who have had hip replacement. At admission to the hospital, first of all, appoint adequate analgesic therapy (ketalong, tramadol, dexalgin, dynastat, stadol, promedol, omnopon, morphine), assess the severity of concomitant diseases, and, if necessary, appoint consultations with relevant specialists. Conduct prevention of stagnation of the lungs and kidneys - training with an instructor exercise, breathing exercises and exercises for the upper and healthy extremities.

Pollyakh [13] also identifies periods of rehabilitation: preoperative and postoperative period, which in turn is divided into a period of relative rest (2-3 days), and a period of recovery of basic skills and functions. However, in general rehabilitation can be divided into two periods: preoperative and postoperative. In the first period, calmness prevails the limb is placed in a derotation longette, passive limb exercises and turns in the bed are performed - after restoring the sensitivity of the patients, they return to the healthy side with a pillow between the knee joints and back to the back every 40 minutes 1.5 hours depending on the condition and the wishes of the patient, perform breathing exercises. Exercise therapy is used in the form of therapeutic and morning hygienic gymnastics, independent classes. Complexes consist of approximately $75 \%$ of developmental and respiratory exercises in a 1: 1 ratio and up to $25 \%$ of special exercises. Perform them mainly from the starting position lying down. The intensity of the exercises was low and at the end of the period moderate. Duration of therapeutic gymnastics 5-12 minutes. The physiological load curve, which is an image of the change in pulse rate during a session, is a single peak in the middle of the main part of the session. Classes include breathing exercises (8-10 deep breaths at the end of each hour), static and dynamic exercises for the toes, isometric tension of the muscles of the forearm, hips and lower leg. Isometric muscle tension is of great importance for the restoration of limb strength. First, the instructor teaches to strain the muscles on a healthy limb, and then for two at a time. The exercise is performed as follows: 1) muscle tension for 3-4 seconds; 2) muscle relaxation for 8-10 seconds. The second period is dominated by exercises aimed at developing all muscle groups.

Classes with the instructor of therapeutic physical training after surgery 2-3 times a day for 1520 minutes to teach patients to perform exercises to restore strength and function of muscles. Mobility in the hip joint depends on: large gluteal muscle flexion, middle gluteal muscle - support function, quadriceps femur and iliac-lumbar muscle - flexion. For restoration of function of muscles of a limb appoint movements of fingers from a foot and in an ankle joint, circular movements of a foot and capture by fingers of a foot, movements in knee joints, bending and extensions, bringing and taking in hip joints, isometric tension of a muscle of a hip. 4-6 seconds with increasing number of repetitions and sessions [13].

Therapeutic massage is used in all periods of rehabilitation treatment after hip replacement. Use segmental reflex, drainage, healing and hardware types of massage. Therapeutic massage is prescribed by the methods of Eremushkin [15], Mukhin [16], Efimenko [10], Glynnaya [14], Zamorsky [5].

Roy et al [11, 17] summarized and systematized studies on the use of physiotherapy methods after hip replacement in various postoperative periods.

According to the Ukrainian authors [18], in the early postoperative period (4-7 days after endoprosthesis), patients are prescribed ultra-high 
frequency therapy (UHF), amplitude or laser therapy, transverse or longitudinal electrophoresis, general ultraviolet radiation. The efficiency of application of the complex of magnetotherapy and ultraphonophoresis (UFF) of chondroxide on both preand postoperative period at the action on the contralateral joint is substantiated.

Belarusian scientists apply physiotherapy treatment in the early rehabilitation period: electrophoresis of calcium-phosphorus preparations on the hip area, sinusoidal modulated currents (CMC) on the lumbosacral spine, laser therapy on the area of the operated joint 5 and the paravertebral joint 1 area of the operated joint, acupuncture [19].

Russian authors recommend that in the early postoperative period, apply ultraviolet irradiation with small erythema doses to the area of postoperative sutures and ultra-high frequency therapy or magnetotherapy to the site of the operated joint for 2-3 days, calcium electrophoresis 12-12 days. After 10-12 weeks after surgery in an outpatient or sanatorium setting, heat therapy (therapeutic muds, paraffin, ozokerite) should be prescribed, with poor tolerability of the mud solution by constant or impulse (sinusoidal modulated currents and diadynamic therapy).

Electromyostimulation of the quadriceps and gluteal muscles of the operated limb is recommended for use by all authors both in the early (4 days) and in the late postoperative periods [20,21, 22].

\section{Conclusions}

1. The program of use of the following measures was developed: medical physical education (the basis of the complexes of medical gymnastics were step-down exercises with visual control and exercises with an elastic band on a healthy leg for balance training); therapeutic massage by Yefimenko method; physiotherapy by standard methods: electromyostimulation; laser therapy.

2. In the experimental group, after the implementation of physical therapy measures under the advanced program, patients' quality of life scores were significantly higher $(p<0.05)$ compared to the control group.

3. The results of the study proved the effectiveness of the impact of physical therapy measures on an improved program on quality of life after hip replacement in the training period.

Prospects for further research are related to the development of an algorithm for physical therapy after hip replacement.

\section{Acknowledgements}

The study was conducted within the priority thematic area 76.35. "Medical-biological substantiation of carrying out restorative means of physical rehabilitation to young people of different level of training". State registration number is $0116 \mathrm{U} 004081$.

\section{Conflict of interest}

Authors state $\mathrm{n}$ o conflict of interest.

\section{References}

1. Babova IK. Organization of rehabilitation treatment of patients after hip replacement in the rehabilitation wards. Medical rehabilitation, balneology, physiotherapy. 2010;1:54-57. (in Ukrainian)

2. Korzh MO. The current state of the problem of joint replacement in Ukraine. Pain, joints, spine. 2012;1(05):10-12. (in Ukrainian)

3. Mansirov Asif Baglar ogli, Litovchenko VO, Bezyazychna OV. Impact of rehabilitation measures on the quality of life of patients after hip replacement. Physical rehabilitation and recreational and recreational technologies. 2018;1:11-17. (in Ukrainian)

4. Babova IK. Spa rehabilitation of patients after hip arthroplasty. Dis. doctor of medical sciences. Crimean Republican Institution «Scientific Research Institute of Physical Methods of Treatment and Medical Climatology named after I.M. Sechenova, Crimea. 2011. (in Ukrainian)

5. Zamorsky TV, Buchinsky SN. Recovery after hip replacement. Kiev, 2017:76. (in Ukrainian)

6. Babova IK, Torchinsky VP, Bila II, Mayko VM. An algorithm for the rehabilitation of patients requiring hip replacement. Bulletin of orthopedics, traumatology and prosthetics. 2010;2:30-35. (in Ukrainian)

7. Kostenko IF. Human health screening and assessment: a textbook. Kiev: Medicine. 2014:278. (in Russian)

8. Polkovnik-Markova VS. Features of examination of the musculoskeletal system in physical rehabilitation. Physical rehabilitation and recreational and wellness technologies. 2016;3:173-179. (in Ukrainian)

9. Epifanov VA, Epifanov AV. Rehabilitation in traumatology and orthopedics: a textbook. Moscow: Geotar-Media. 2015:416. (in Russian)

10. Efimenko PB. Massage technique and technique: a textbook for higher education students. Kharkiv: Kharkiv state academy of physical education. 2013:296. (in Ukrainian)

11. Roy IV, Babova IK, Lazarev IA. The use of physiotherapy methods in patients with orthopedictraumatic profile after metal osteosynthesis and endoprosthesis. Trauma. 2010;2(11):226-230. (in Ukrainian)

12. Gliniana OO. Physical rehabilitation of elderly people with cementitious hip replacement. Thesis for a candidate of science degree in physical education and sports 24.00.03 - physical rehabilitation. Kiev;2013:21. (in Ukrainian) 
13. Gerasimenko SI, Roy IV, Polulyaj DM. Rehabilitation after endoprosthesis of patients with severe type of hip dysplasia. Trauma. 2016;17(5):72-75. (in Ukrainian)

14. Gliniana OO, Papadyuja YA. Algorithm for rehabilitation after primary hip replacement. Pedagogy, psychology and medical and biological problems of physical education and sports. 2011;8:3032. (in Ukrainian)

15. Eremushkin MA. Classical massage technique for injuries and diseases of the musculoskeletal system: a reference manual. St. Petersburg: Science and Technology. 2010:192. (in Ukrainian)

16. Muhin VM. Physical rehabilitation: a textbook for students of higher education in physical education and sports. Kiev: Olympic literature. 2009:488. (in Ukrainian)

17. Roy IV, Babova IK, Lazarev IA, Vorobey VV, Buchinsky SN, Mayko VM. The use of physiotherapy methods in patients with orthopedic-traumatic profile after metalosteosynthesis and endoprosthetics (literature review). Trauma. 2010;2(11):226-230. (in Ukrainian)

18. Roy IV. Physiotherapy treatment of patients with orthopedic and traumatic profile. Surgical treatment, medical rehabilitation, physiotherapy for bone fractures and joint diseases: Materials of scientificpractical conference with international participation. Kiev. 2008:97-98. (in Ukrainian)

19. Medvedev LF, Maslov AP, Kazak LG. Medical rehabilitation of patients after total hip arthroplasty. Instructions for use ministry of health of the republic of Belarus, Registration No 50-0302. 2003:23. (in Ukrainian)

20. Kurbanov SJ. Individual rehabilitation of patients after hip arthroplasty. Abstract of the dissertation of doctor of medical sciences. St. Petersburg. 2008:32. (in Ukrainian)

21. Roy IV, Babova IK, Bayandina OI. Technology of rehabilitation of patients after hip arthroplasty. Bulletin of orthopedics, traumatology and prosthetics. 2010;4:35-38. (in Ukrainian)

22. Babov KD. Actual problems of early rehabilitation of patients after hip joint replacement. The International scientific congress The 60-th Session of General Assembly of the World Federation of Hydrotherapy and Climatotherapy. Italy. 2007:156. (in Italy)

\section{Information about the authors}

Bezyazychna. O.V. obdyazychnaya@gmail.com orcid.org/ 0000-0001-9987-6405

Kharkiv State Academy of Physical Education st. Klochkivska, 99. Kharkiv, 61058, Ukraine

\section{Manucharyan S.V.}

mybox3001@ukr.net

orcid.org/0000-0001-7256-3273

Kharkiv State Academy of Physical Education st. Klochkivska, 99. Kharkiv, 61058, Ukraine

\section{Dugina LV.}

lianadugina@gmail.com orcid.org/ 0000-0002-4278-4830

Kharkiv State Academy of Physical Education st. Klochkivska, 99. Kharkiv, 61058, Ukraine

\section{Інформація про авторів}

\section{Без'язична О.В.}

obezyazychnaya@gmail.com

orcid.org/ 0000-0001-9987-6405

Харківська державна академія фізичної культури вул. Клочківська, 99. Харків, 61058,Україна

\section{Манучарян C.B.}

mybox3001@ukr.net

orcid.org/0000-0001-7256-3273

Харківська державна академія фізичної культури вул. Клочківська, 99. Харків, 61058, Україна

\section{Дугіна Л.В.}

lianadugina@gmail.com orcid.org/ 0000-0002-4278-4830

Харківська державна академія фізичної культури вул. Клочківська, 99. Харків, 61058, Україна 